\title{
MEDNARODNA KONFERENCA EUROGEO 2004 - GEOINFORMATIKA $\vee$ GEOGRAFSKI UČILNICI
}

Mednarodna konferenca EUROGEO 2004 na temo geoinformatike v geografski učilnici je, potekala od 7. do 9. 5. 2004 na Bledu. Udeležencev iz številnih evropskih držav je bilo 52, od tega 12 predavateljev. EUROGEO je mednarodna organizacija, ki deluje že 25 let, in združuje evropska društva učiteljev geografije.

Uvodno predavanje je imel A. Gosar, ki je predstavil Slovenijo predvsem z družbenogeografskega vidika. V nadaljevanju je A. Bosschart iz Nizozemske predstavil rezultate pravkar zaključenega 3-letnega projekta EURO.GEO, v katerem je sodeloval tudi Oddelek za geografijo Filozofske fakultete v Ljubljani. Največ poudarka je bilo na predstavitvi spletnih strani, priročnika o državljanski vzgoji ter interaktivnih zemljevidov. Udeleženci so si nato ogledali računalniško predstavitev posameznih projektnih tem - ljudje, kraji, regije, okolje.

Dopoldanski del drugega dne konference je bil v celoti posvečen geoinformatiki in geografiji. J. Sowle (Velika Britanija) je predstavil Dakini projekt - projekt o geoinformacijskih sistemih ( $v$ nadaljevanju GIS), $v$ katerem so sodelovale britanske in francoske šole, K. E. Christensen (Danska) se je spraševal o posledicah uvedbe GIS-ov kot orodja v učnem procesu, N. Lambrinos (Grčija) je govoril o GIS-ih in geografski vizualizaciji, C. Brooks (Velika Britanija) pa je predstavila The YoungNet projekt.A. Koller (Avstrija) je osvetlil geoinformatiko v Avstriji in njeno uporabo v šolah, C. Durbin (Velika Britanija) je govoril o geografiji in GIS-ih, P. Brogger Sorensen (Danska) je predstavil delovanje »Eduspace - The European Space Agency«, G. Falk (Nemčija) pa je razmišljal o GIS-ih v geografski učilnici s poudarkom na metodah, prednostih in omejitvah. Predavanjem je sledila razprava.

V popoldanskem času so udeleženci odšli na ekskurzijo v Ljubljano, na Cerkniško jezero ter v Postojno. Ekskurzijo sta vodila J. Kunaver in L. Zornik.

Tretji dan je potekala računalniška delavnica na temo zemljevidov sveta in Evrope pod vodstvom G. Dalleya (ZDA). Poudarjen je bil pomen geografskega mišljenja in hitro razvijajoče se tehnologije GIS-ov , katerih uporaba postaja vitalni del študentskih, akademskih, delovnih in državljanskih veščin.

Konferenca se je zaključila s poročili o delu EUROGEO ter njegovih nalogah $\mathrm{v}$ prihodnosti. Naslednja država gostiteljica bo leta 2005 Poljska.

Prispevki in materiali konference bodo objavljeni na spletnih straneh EUROGEO ter na cd-romu.

Tatjana Resnik Planinc 